\title{
Relative Chronology in High-Grade Crystalline Terrain of the Eastern Ghats, India: New Insights
}

\author{
Samarendra Bhattacharya ${ }^{1}$, Rajib Kar ${ }^{2}$, Amit Kumar Saw ${ }^{3}$, Prasanta Das ${ }^{4}$ \\ ${ }^{1}$ Indian Statistical Institute, Kolkata, India \\ ${ }^{2}$ J.K. College, Purulia, India \\ ${ }^{3}$ National Mineral Development Corporation Limited, Hyderabad, India \\ ${ }^{4}$ Uranium Corporation of India Limited, Turamdih, India \\ E-mail: samar.bhattacharya@gmail.com \\ Received May 27, 2011; revised July 25, 2011; accepted September 7, 2011
}

\begin{abstract}
The two major lithology or gneiss components in the polycyclic granulite terrain of the Eastern Ghats, India, are the supracrustal rocks, commonly described as khondalites, and the charnockite-gneiss. Northern Eastern Ghats belt, north of the Godavari rift has been defined as the Eastern Ghats Province, while that to the south has been defined as the Ongole domain; and although, these distinct crustal domains also record different ages of granulite metamorphism, both of these domains are dominated by the two lithologies. Many of the workers considered the khondalites as the oldest component with unknown basement and the charnockiteprotoliths as intrusive into the khondalites. However, published geochronological data do not corroborate the aforesaid relations. Onset of khondalite sedimentation in the Proterozoic Eastern Ghats Province, constrained by detrital zircon data, as around 1.3 Ga and the charnockite-protolith emplacement between 1.9 and $2.9 \mathrm{Ga}$, argue against intrusion of felsic magma (tonalite, now enderbite!) in to the khondalites. The field relations of the hornblende-mafic granulite with the two gneiss components together with $\mathrm{Sm}-\mathrm{Nd}$ isotopic data of the hornblende-mafic granulites (both the xenoliths within charnockites and those interbanded with the khondalites) indicate that khondalite sediments were deposited on older mafic crustal rocks. Mafic basement and supracrustal rocks were subsequently deformed and metamorphosed together during collisional orogeny at high to ultra-high temperatures - partial melting of mafic rocks producing the charnockitic melt; and partial melting of pelitic sediments producing the peraluminous granitoids. This is compatible with all the geochronological data as well as the petrogenetic model of partial melting for the charnockitic rocks in the Eastern Ghats Belt. The Ongole domain, south of the Godavari rift, though, is distinct in terms of the age of first/ earliest UHT metamorphism, but here too the charnockite-protoliths are older mafic rocks evidently not intrusive in to the khondalites..
\end{abstract}

Keywords: Hornblende-Mafic Granulite, Xenolith, Interbanded, Mafic Basement, Partial Melting.

\section{Introduction}

High-grade crystalline terrains are characterized by gneissic fabrics resulting from tectonic and metamorphic processes and hence do not reflect the original stratification of the sedimentary or volcanic protoliths [1]. Moreover, many of the high-grade terrains have suffered polyphase deformation and metamorphism, which further complicate the relative chronological relation between different units or gneiss-components. It is imperative then to distinguish the different generations of the gneissic fabrics in different components. Finally application of geochronological methods is useful to reconstruct the history of the crystalline terrains. The Eastern Ghats Granulite Belt, India, with polyphase deformation and complex metamorphic record may be taken up as a case study.

\section{Geological Background}

The Eastern Ghats Belt along the east coast of India comprises several rock types that can be grouped into the 
following: a) metapelitic granulites including khondalite, quartzite and calc-granulite (supracrustals); b) charnockitic gneisses; c) mafic granulites; d) migmatitic gneisses including garnetiferous granite gneisses and leptynites; e) anorthosites; and f) alkaline complexes (Figure 1). Detailed field studies in several sectors have revealed three phases of folding with development of pervasive foliations, often truncating and transposing earlier fabrics on different scales [2-4]. On regional-scale gneissic foliations $S_{1}$ and $S_{2}$ are parallel and may be described as a $\mathrm{S}_{1}-\mathrm{S}_{2}$ composite fabric. Isoclinal and rootless $\mathrm{F}_{1}$ folds with a NE-SW trending steep axial-plane foliation, $\mathrm{S}_{1}$ and common structural repetitions suggest a regional NW-SE directed compression and shortening during the development of first generation folds [4]. Beside the polyphase deformation history, the Eastern Ghats Belt is also characterized by polycyclic metamorphic record and dehydration melting in different crustal protoliths [5-9]. However, in view of different crustal residence ages from different parts of the regional granulite terrain, as also distinct isotopic records of granulite facies metamorphism across this regional granulite terrain, the tectonic-metamorphic evolution should be discussed separately for the different crustal domains \& provinces identified [10,11]. Barring the Archean domains of Ren-

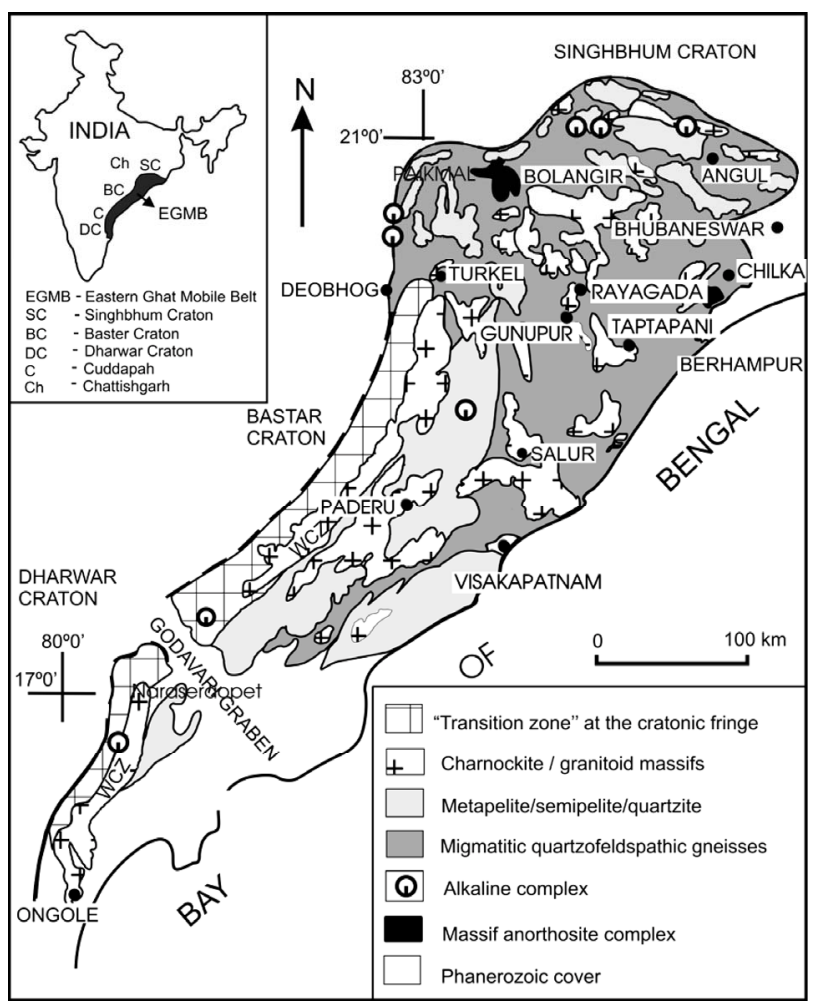

Figure 1. Generalized geological map of the Eastern Ghats Belt, modified after Ramakrisnan et al., [36], showing the broad lithological distributions. gali and Jaypore, the northern Eastern Ghats Belt, north of the Godavari rift is now described as the Eastern Ghats Province (EGP) and south of the Godavari rift is the Ongole domain (Figure 2).

Both clockwise and anti-clockwise P-T-t paths have been reported from different parts in the EGP and two contrasting tectonic interpretations have been proposed $[8,12,13]$. Sengupta et al. related the anti-clockwise P-T-t path with "compressive orogeny that was associated with high heat flux through mafic magmatism". According to these authors granulite metamorphism was caused by magmatic underplating, as in the model of Bohlen [14]. But Bhattacharya et al. [15] argued against the magmatic underplating causing granulite metamorphism, on the grounds that mafic magmatism (given by Nd-model dates of mafic granulites) and granulite metamorphism (given by $\mathrm{U}-\mathrm{Pb}$ zircon dates) are different events, widely separated in time. On the other hand, the reported clockwise P-T-t paths were interpreted by Bhattacharya and Kar [8] as the result of homogeneous shortening in a compressional setting. In this context it may be noted that Thompson [16] concluded that "a simple orogenic clockwise P-T path of burial, heating, exhumation, then cooling will result in dehydration melting reactions during the heating and decompression phases".

Despite such divergent interpretations, high to ultrahigh temperatures $\left(\geq 950^{\circ} \mathrm{C}\right)$ and dehydration melting in different crustal protoliths are commonly associated with the first or earliest granulite facies metamorphism in the Eastern Ghats Province [17,18]. The high to ultra-high temperature records and the P-T-t paths reported from the Eastern Ghats Belt are summarized in Figure 2. Although, there is still some debate for the timing of this high temperature event, Mukhopadhyay and Basak [18] argued that the early UHT metamorphic event affected the entire EGP; these authors also noted that the absence of UHT assemblage in some locales may be due to the absence of suitable bulk composition. Simmat and Raith [17] also noted that the earliest and ultra-high temperature granulite metamorphism is recorded from both pelitic and charnockitic assemblages.

\section{Charnockite-Khondalite Relation}

One significant outstanding issue concerning the tectonometamorphic evolution in the Eastern Ghats Belt is the relation between the khondalites and charnockites, the two major gneiss components. In this communiqué we focus on this problem, both in terms of field relations and petrological and isotopic relations. In conjunction with our earlier publications, additional field features and some new isotopic data presented here, led us to propose a new tectonic interpretation of the early/first, and high 


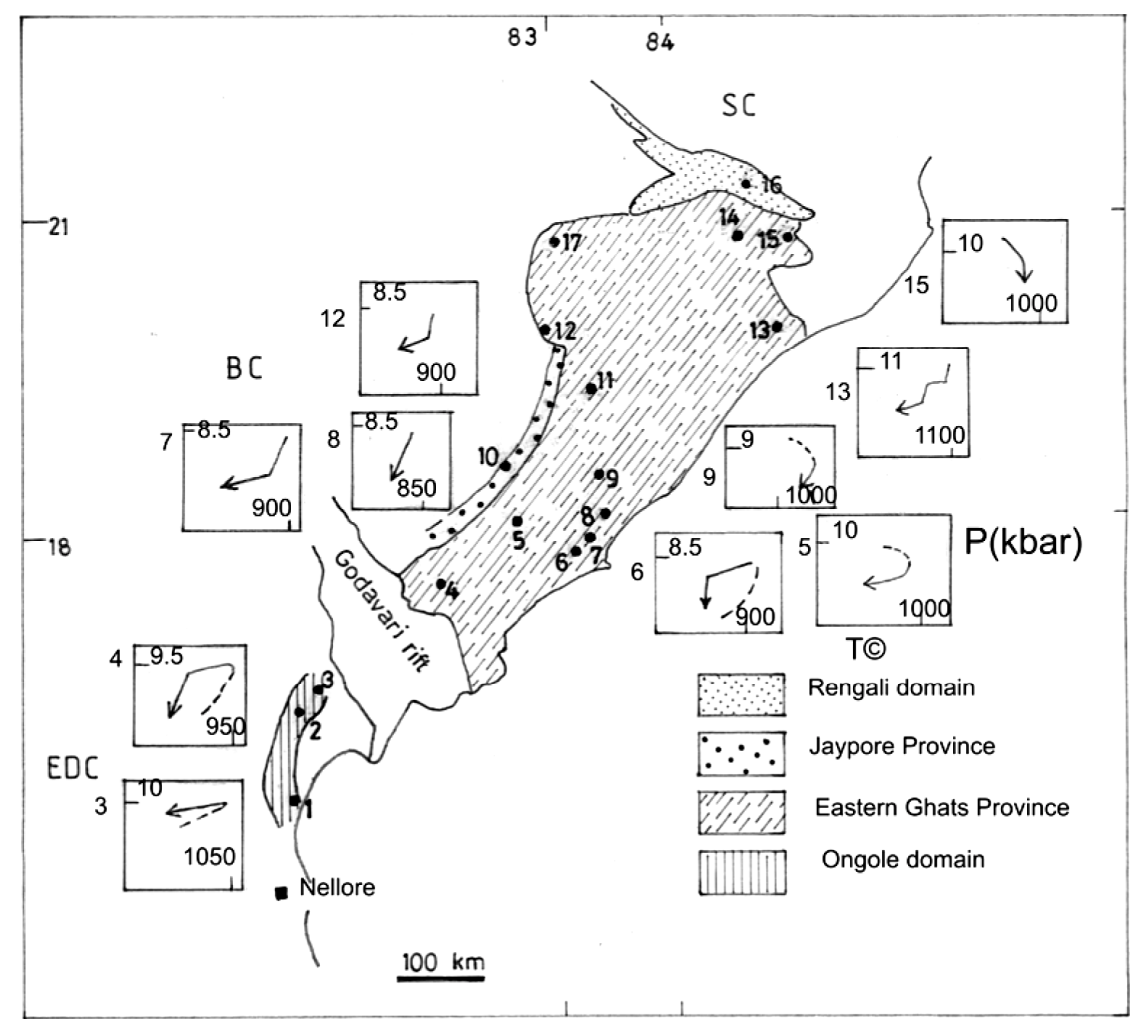

Figure 2. Different crustal domains of the Eastern Ghats Belt; or provinces shown. Important locations also shown. 1. Ongole, 2. Naraseraopet, 3. Kondapalle, 4. Rajamundri, 5. Paderu, 6. Anantagiri, 7. Anakapalle, 8. Garbham, 9. Sunki, 10. Jaypore, 11. Rayagada, 12. Deobhog, 13. Chilka, 14. Angul, 15. Jenapore, 16. Rengali, 17. Paikmal. P-T paths reported from different locations are shown in boxes.References to the above: 3: [31]. 4: [32]. 5: [8]. 6: [12] 7: [5] 8: [33]. 9: [34]. 12: [35] 13: [6] 15: [9].

to ultra-high temperature granulite metamorphism, that is separately applicable for the EGP and the Ongole domain.

The Sm-Nd whole-rock isotopic analyses were carried out at the Center of Research in Geochronology of Sao Paulo University, Brazil, using the two-column technique, as described by Richard et al. [19] with the addition of some improvements. An ion exchange resin was used for primary separation of the REE, followed by a second HDEHP-coated Teflon powder column for separation of $\mathrm{Sm} \& \mathrm{Nd}$. The $\mathrm{Sm} \& \mathrm{Nd}$ abundances were determined by isotope dilution. The isotope ratios were measured on a VG 354 multi-collector mass spectrometer. The measured ratio of ${ }^{143} \mathrm{Nd} /{ }^{144} \mathrm{Nd}$ obtained for La Jolla standard was $0.511857 \pm 0.000046(2 \sigma)$. The laboratory blanks for the chemical procedure during the period of analysis yielded maximum values of $0.4 \mathrm{ng}$ for $\mathrm{Nd}$ and $0.7 \mathrm{ng}$ for $\mathrm{Sm}$. Nd-model dates $\left(\mathrm{T}_{\mathrm{DM}}\right)$ are calculated using depleted mantle model of DePaulo [20].

It is intriguing that in the Eastern Ghats Belt, hornblende-mafic granulites with abundant prograde hornblende, are not recognized or ignored by most of the workers. Here we demonstrate the significance of the hornblende-mafic granulites, both in terms of their field relations with the charnockitic gneiss and the metasedimentary granulites, and in terms of the petrological and isotopic relations.

In the Eastern Ghats Belt, hornblende-mafic granulites occur as xenoliths within massif-type charnockites in both the Eastern Ghats Province and the Ongole domain (Figure 3). Our petrogenetic studies indicate charnockitic melt as product of partial melting in mafic rocks under granulite facies conditions [9,15,21]. Hence the protoliths of the charnockite-gneiss are mafic rocks, now represented by the hornblende-mafic granulites. This mafic magmatism may be represented by $\mathrm{T}_{\mathrm{DM}}$ (crustal residence ages) of the protoliths of charnockitic gneiss as between 1.9 and $2.9 \mathrm{Ga}$ [10]. Our Sm-Nd isotopic data on hornblende-mafic granulite xenoliths of both the Eastern Ghats Province (Sunki and Paderu) and Ongole domain (Naraseraopet) indicate the mafic magmatism around $2.5 \mathrm{Ga}$ [22]. Hornblende-mafic granulites also occur interbanded with the khondalites at several locations (Figure 4). It is interesting to note that these minor bands of hornblende-mafic granulites interbanded with the khondalites have similar mineralogy, namely with 


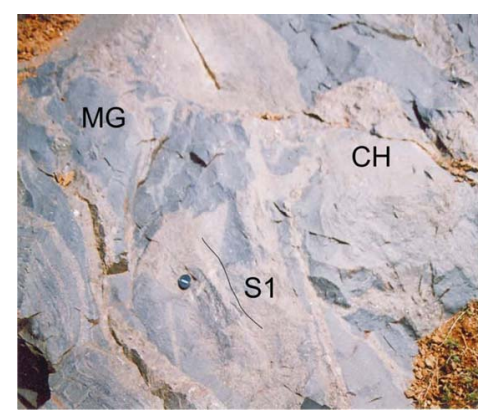

(a)

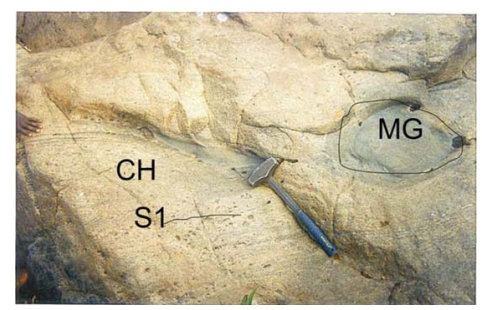

(b)

Figure 3. (a) Mafic granulite xenoliths in massif-type charnockite at Naraseraopet of the Ongole domain. $S_{1}$ gneissic foliation in host charnockitic gneiss marked. $\mathrm{CH}=$ charnockite; MG = mafic granulite; (b) Mafic granulite xenoliths in massif-type charnockite at Sunki of the Eastern Ghats Province. $S_{1}$ gneissic foliation in host charnockitic gneiss marked.

abundant prograde hornblende (Figure 5). Sm-Nd whole rock isotopic data of these mafic granulites interbanded with the khondalites indicate the emplacement of their protoliths, the mafic magmatism, between 1.9 and $2.9 \mathrm{Ga}$ (Table 1). That similar dates were reported by Rickers et al. [10] for the precursors of charnockite-enderbite, may not be fortuitous and highlights the fact that hornblende-mafic granulites in both the associations (xenoliths within charnockitic rocks and interbanded with the khondalites) represent the same entity.

\section{Discussion}

\subsection{Field Relation and Fabric Development}

Although several reports have been published, correlation of deformational events and attendant gneissic foliation, in different areas or in different lithologies in the same area still remains problematic. In terms of field relation between two major gneiss components, several workers have argued that khondalites or the sedimentary granulites are the oldest components (supposed xenoliths), and multiply intruded by magmatic rocks, including enderbites and charnockites [10,17]. However, the question of the basement to these sediments remains illusive. On the other hand, correlation between gneissic

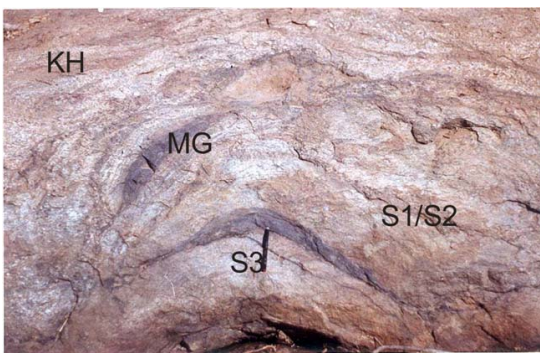

(a)

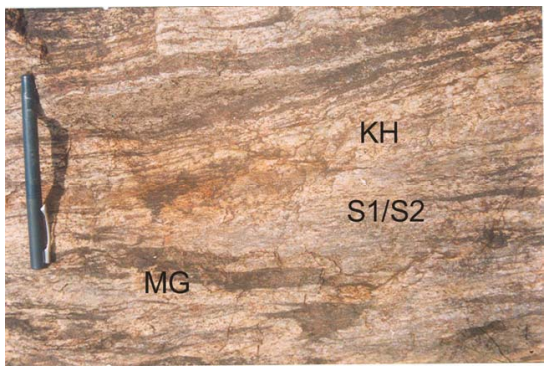

(b)

Figure 4. (a) Minor mafic granulite bands interbanded with khondalites and folded together, at Sunki of the Eastern Ghats Province. $S_{1}-S_{2}$ composite foliation shows broad warp; axial trace, $S_{3}$ is marked by the pen. $\mathrm{KH}=$ khondalite; MG $=$ mafic granulite. (b) Mafic granulite interbanded with the khondalite at Naraseraopet of the Ongole domain. $S_{1}-S_{2}$ composite fabric marked.

fabrics in the two components remains debatable. From the Chilka Lake area, Bhattacharya et al., [2] proposed a generalized deformation history from similar styles of deformation and fabric development in the two major gneiss-components, namely the metasedimentary granulites and charnockitic rocks. Also from the same area Dobmeier and Raith [23] observed "the enderbitic and metasedimentary rocks have identical structural history". But from Angul area Mukhopadhyay and Basak [18] noted that "gneissosity in khondalites formed earlier than that in the charnockitic gneisses, though the two are generally parallel".

\subsection{Geochronology}

During the last decade or so significant isotopic data on different granulite lithologies have been published; but still these could not resolve the problem of the chronological relation between metasedimentary granulites and charnockitic gneiss. The metasedimentary granulites are thought as the oldest component and intruded by magmatic rocks, enderbites and charnockites [10,17]. It is important to note that coarse-grained pegmatitic charnockites are commonly recognized as distinct from the large-scale charnockitic bodies and an intrusive relation of this pegmatitic variety into khondalites was reported 


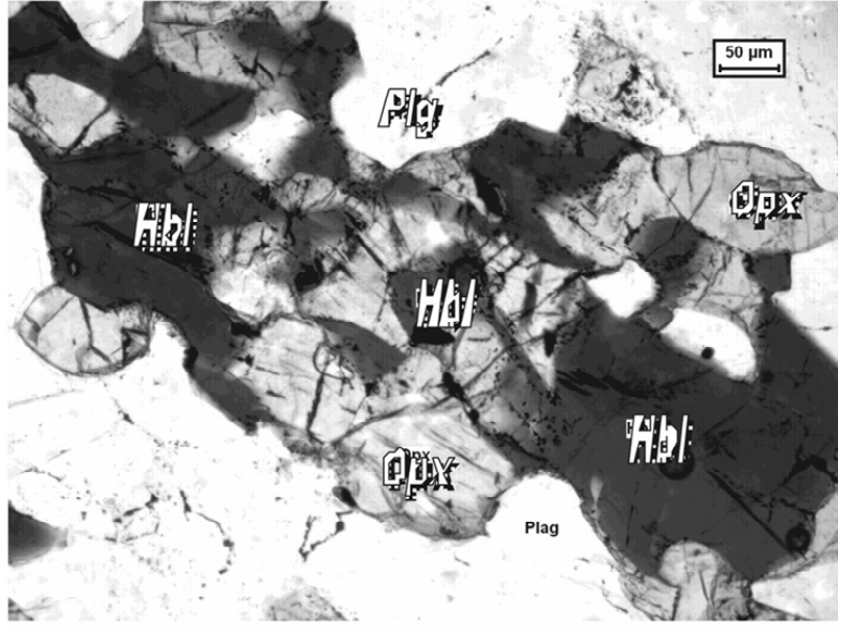

Homblende-mafic granulite interbanded with khondalite at Naraseraopet

(a)

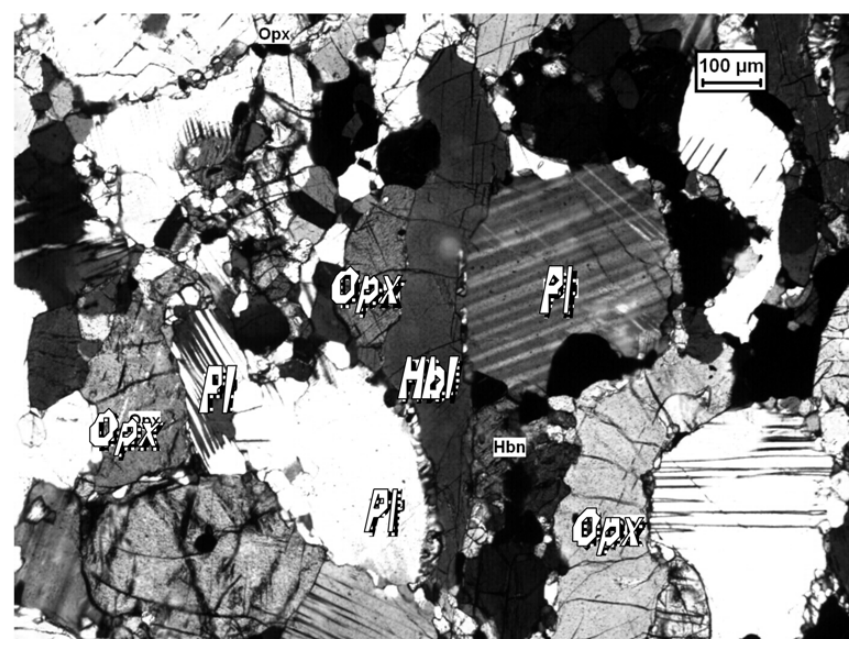

Horrblende-mafic granulite interbanded with khondalite at Surki

(c)

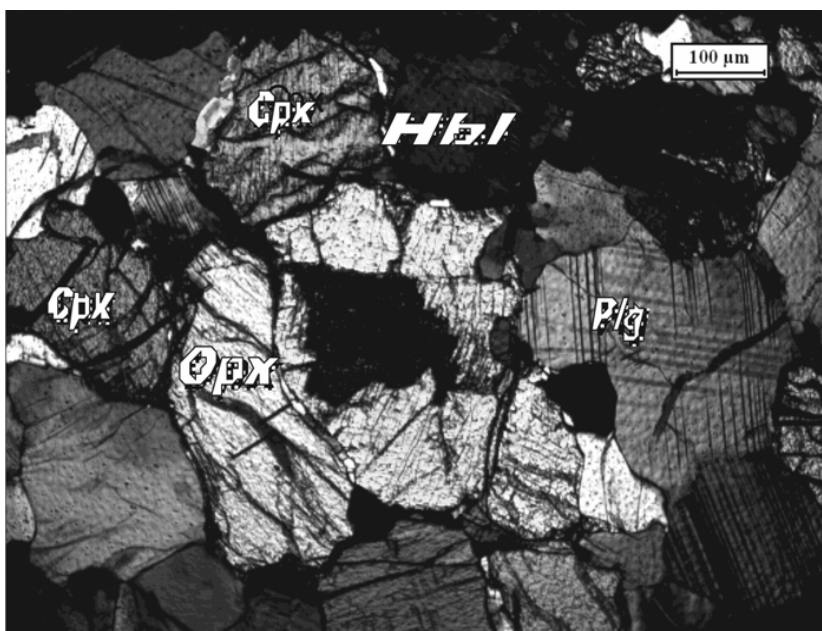

Homblende-mafic granulite interbanded with khondalite at Paikmal

(b)

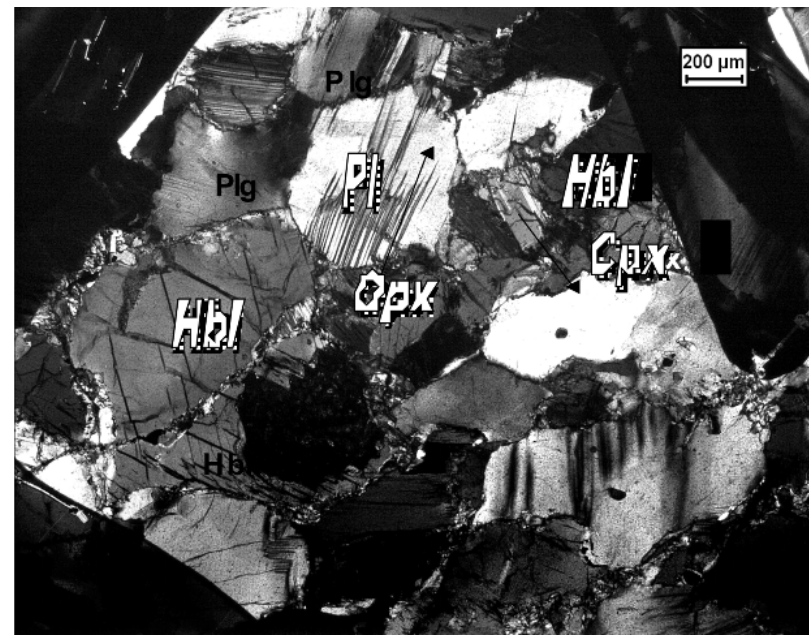

Horrblende-mafic granulite interbanded with khondalite at Paderu

(d)

Figure 5. Photomicrographs of hornblende-mafic granulites interbanded with khondalites from different locations.

Table 1. $\mathbf{T}_{\mathrm{DM}}$ ages for mafic granulites interbanded with the khondalites.

\begin{tabular}{|c|c|c|c|c|c|c|c|}
\hline Location & Lat \& Long & Sample & $\mathrm{Sm}(\mathrm{ppm})$ & $\mathrm{Nd}(\mathrm{ppm})$ & ${ }^{147} \mathrm{Sm} /{ }^{144} \mathrm{Nd}$ & ${ }^{143} \mathrm{Nd} /{ }^{144} \mathrm{Nd}$ & $\mathrm{T}_{\mathrm{DM}}(\mathrm{Ga})$ \\
\hline Paikmal & $\begin{array}{l}20^{\circ} 50^{\prime} 48^{\prime \prime} \mathrm{N} \\
82^{\circ} 44^{\prime} 36^{\prime \prime} \mathrm{E}\end{array}$ & $4 \mathrm{P} / 05$ & 3.77 & 14.274 & $0.1597 \pm 9$ & $0.512375 \pm 9$ & 1.9 \\
\hline Paderu & $\begin{array}{l}18^{\circ} 7^{\prime} 46.8^{\prime \prime} \mathrm{N} \\
82^{\circ} 39^{\prime} 28.8^{\prime \prime} \mathrm{E}\end{array}$ & $\mathrm{Pa} 34 \mathrm{C}$ & 3.775 & 14.604 & $0.1563 \pm 6$ & $0.511940 \pm 12$ & 2.9 \\
\hline Sunki & $\begin{array}{c}18^{\circ} 26^{\prime} 46.8^{\prime \prime} \mathrm{N} \\
83^{\circ} 0^{\prime} 52.8^{\prime \prime} \mathrm{E}\end{array}$ & $\mathrm{D} 2 / 2$ & 6.17 & 24.35 & $0.1532 \pm 7$ & $0.511999 \pm 8$ & 2.7 \\
\hline Naraseraopet & $\begin{array}{c}16^{\circ} 4^{\prime} 22.3^{\prime \prime} \mathrm{N} \\
80^{\circ} 1^{\prime} 28^{\prime \prime} \mathrm{E}\end{array}$ & $\mathrm{A} 5 / 1$ & 6.02 & 22.36 & $0.1629 \pm 5$ & $0.512216 \pm 11$ & 2.8 \\
\hline
\end{tabular}

by Subba Rao and Divakara Rao [24]. But an intrusive relation of the large-scale charnockitic bodies into the metasedimentary granulites (supracrustals) is not corroborated by the published isotopic data, as discussed in the following lines.

Based primarily on Nd-mapping, several crustal domains or provinces with unrelated pre-metamorphic histories have been identified in the Eastern Ghats Belt [10, 
11]. Moreover, considering the metamorphic records in terms of their age two provinces are also recognized. The north and central parts of the Eastern Ghats Belt, north of the Godavari rift, is now described as the Proterozoic Eastern Ghats Province and the earliest granulite event in this province is recorded as $1.2 \mathrm{Ga}$ [17]. South of the Godavari rift is the Ongole domain of the Krishna Province, and the earliest granulite event in this domain is recorded as around $1.6 \mathrm{Ga}$ [25]. This $1.6 \mathrm{Ga}$ metamorphism and partial melting has been recorded from both metapelites and charnockitic gneiss [15,17]. It is imperative that the relative chronology between the two gneiss components should be discussed separately for the aforesaid two provinces or domains.

In the Eastern Ghats Province, Simmat and Raith [17] suggested that " $\mathrm{U}-\mathrm{Pb}$ detrital zircons preserved in metapelitic granulites and high-Mg-Al granulites provide an upper age limit of $\sim 1.37 \mathrm{Ga}$ for the deposition of sediments". Also these authors indicated the earliest granulite facies metamorphism of $1.2 \mathrm{Ga}$ in the EGP. These authors further suggested that in the Chilka Lake area (EGP) the metasedimentary granulites "form the oldest component" and "it was intruded by concordant bodies of tonalite (now enderbite) of unknown age..." These authors also suggested that in the eastern khondalite domain (Anakapalle area in EGP) "high-grade supracrustal package was intruded by basic magmas (two-pyroxene granulites)". It is evident from these data and interpretations that intrusion of charnockite-gneiss protolith must be younger than $1.37 \mathrm{Ga}$. But according to the hypothesis of charnockitic magmatism and emplacement (tonalite) followed by granulite metamorphism [17,26], the intrusion of charnockite-gneiss protolith must be older than $1.2 \mathrm{Ga}$. On the other hand, Rickers et al. [10] indicated that intrusion of the charnockite-gneiss protolith is given by $\mathrm{T}_{\mathrm{DM}}$ as between 1.9 and $2.9 \mathrm{Ga}$. It is evident from the aforesaid discussions that neither the khondalites as the oldest component, nor the intrusion of charnockite-gneiss protolith into the metasedimentary granulites (supracrustals) are valid propositions.

Similar problem is encountered for the Ongole domain. Simmat and Raith [17] indicated that "high to ultra-high grade metamorphism occurred between 1650 and 1540 $\mathrm{Ma}$, after the emplacement of basic and felsic plutonic complexes into the supracrustal granulites at ca. $1.7 \mathrm{Ga}$ ". Bhui et al. [26] also described "intrusion of a suite of voluminous felsic magma (protolith of enderbitic gneiss)" and Kovach et al. [27] suggested that "U-Pb zircon data from the felsic magma provided the emplacement age of the felsic magma at $1.7-1.72 \mathrm{Ga}$ ". Accordingly, the sediment deposition in this domain must be older than $1.7 \mathrm{Ga}$. Although, no unequivocal evidence for the depositional age of the khondalites in the Ongole domain have so far been published, Upadhyay et al. [28] indicated that onset of sedimentation in the Eastern Ghats Belt, could be constrained by the rift-valley Alkaline magmatism of the Prakasam Province at the western margin of the Eastern Ghats Belt, as ca. $1.42 \mathrm{Ga}$. Thus felsic magma emplaced around $1.7 \mathrm{Ga}$ can not be considered as intrusive into the supracrustals of younger depositional age.

In the Eastern Ghats Province considering onset of sedimentation around $1.3 \mathrm{Ga}$, constrained by detrital zircon data reported by Simmat and Raith [17], the basement is most likely the older crustal rocks ( 1.9 to $2.9 \mathrm{Ga}$ mafic rocks reported here; and charnockite-enderbite precursors of Rickers et al. [10]. And the earliest granulite metamorphism at $1.2 \mathrm{Ga}$ involved both the mafic rocks and the supracrustal rocks. High to ultra-high temperature granulite metamorphism of the mafic rocks produced the charnockitic melt by partial melting $[9,21$, 29]. And the same high to ultra-high temperature granulite metamorphism of the supracrustal rocks (including khondalites and high-Mg-Al granulites) produced the peraluminous granitoids $[7,8,30]$.

For the Ongole domain, although no unequivocal evidence for the age of sedimentation is available, it must be older than $1.6 \mathrm{Ga}$, earliest granulite metamorphism recorded from high Mg-Al metapelites and this way Ongole sediment deposition is distinct from that in the EGP, which is said to be related to rifting and alkaline magmatism of the Prakasam Province. However, in terms of field relations the khondalites as the oldest gneiss component is not corroborated by the published isotopic data. But our alternative petrogenetic model, namely, sedimentation on older crustal rocks (1.9 - 2.9 Ga mafic rocks) followed by granulite metamorphism during collisional orogeny in both the sediments and mafic basement around $1.6 \mathrm{Ga}$, is consistent with all the geochronological data published so far as also the field relations of the hornblende-mafic granulites with the two gneiss components. However, 1.7 - $1.72 \mathrm{Ga} \mathrm{U}-\mathrm{Pb}$ data reported from zircons in the Ongole domain, may not be a separate event from the UHT metamorphism that invariably leads to anatexis and hence magmatic zircon morphology. We would like to interpret this age as representing the peak of UHT metamorphism and $1.6 \mathrm{Ga}$ representing the waning phase of the same.

\section{Conclusions}

Older mafic rocks, now represented by the hornblendemafic granulites, were the basement for the khondaliteprotolith sediments, in both the Eastern Ghats Province and the Ongole domain of the Eastern Ghats Belt, India.

Earliest granulite metamorphism, 1.2 Ga in the EGP 
and $1.6 \mathrm{Ga}$ in the Ongole domain involved both the mafic basement and the khondalite sediments.

High to Ultra-high temperature granulite metamorphism of mafic rocks produced the charnockitic melt, and that of pelitic sediments produced the peraluminous granitoids, in the Eastern Ghats Belt.

\section{Acknowledgements}

Indian Statistical Institute has been providing infrastructural facilities, particularly for extensive fieldwork in the Eastern Ghats Belt during the last fifteen years. Government of India provided funds under several Research schemes during this period. GeoScience Institute of Sao Paulo University, Brazil is thankfully acknowledged for providing Isotopic/geochronological data on Eastern Ghats rocks.

\section{References}

[1] J. Rey and S. Galotti (Eds.) "Stratigraphy: Terminology and Practice," Editions Technip, Paris, 2008.

[2] S. Bhattacharya, S. K. Sen and A. Acharyya, "The Structural Setting of the Chilka Lake Granulite-MigmatiteAnorthosite Suite with Emphasis on the Time Relation of Charnockites," Precambrian Research, Vol. 66, No. 1-4, 1994, pp. 393-409. doi:10.1016/0301-9268(94)90060-4

[3] S. Bhattacharya, "Eastern Ghats Granulite Terrain: An Overview," Journal of Southeast Asian Earth Science, Vol. 14, No. 3-4, 1996, pp. 165-174. doi:10.1016/S0743-9547(96)00055-4

[4] S. Bhattacharya, "Evolution of Eastern Ghats Granulite Belt of India in a Compressional Tectonic Regime and Juxtaposition against the Iron Ore Craton of Singhbhum by Oblique Collision-Transpression," Journal of Earth System Science, Vol. 106, No. 3, 1997, pp. 65-75.

[5] S. Dasgupta, S. Sanyal, P. Sengupta and M. Fukuoka, "Petrology of Granulites from Anakapalle-Evidence for Proterozoic Decompression in the Eastern Ghats, India," Journal of Petrology, Vol. 35, 1994, pp. 433-459.

[6] S. K. Sen, S. Bhattacharya and A. Acharyya, "A Multi-Stage Pressure-Temperature Record in the Chilka Lake Granulites: The Epitome of the Metamorphic Evolution of the Eastern Ghats, India?" Journal of Metamorphic Geology, Vol. 13, No. 2, 1995, pp. 287-298. doi:10.1111/j.1525-1314.1995.tb00219.x

[7] S. K. Sen and S. Bhattacharya, "Dehydration Melting of Micas in the Chilka Lake Khondalites: The Link between the Metapelites and Granitoids," Proceedings of the Indian Academy of Sciences (Earth \& Planetary Science), Vol. 106, 1997, pp. 277-297.

[8] S. Bhattacharya and R. Kar, "High-Temperature Dehydration Melting and Decompressive P-T Path in a Granulite Complex from the Eastern Ghats, India," Contributions to Mineralogy and Petrology, Vol. 143, No. 2, 2002, pp. 175-191. doi:10.1007/s00410-001-0341-6
[9] R. Kar, S. Bhattacharya and J. W. Sheraton, "Hornblende Dehydration Melting in Mafic Rocks and the Link between Massif-Type Charnockite and Associated Granulites, Eastern Ghats Granulite Belt, India," Contributions to Mineralogy and Petrology, Vol. 145, No. 6, 2003, pp. 707-729. doi:10.1007/s00410-003-0468-8

[10] K. Rickers, K. Mezger and M. M. Raith, "Evolution of the Continental Crust in the Proterozoic Eastern Ghats Belt, India and New Constraints for Rodinia Reconstruction: Implications from $\mathrm{Sm}-\mathrm{Nd}, \mathrm{Rb}-\mathrm{Sr}$ and $\mathrm{Pb}-\mathrm{Pb}$ Isotopes," Precambrian Research, Vol. 112, No. 3-4, 2001, pp. 183-210. doi:10.1016/S0301-9268(01)00146-2

[11] C. J. Dobmeier and M. M. Raith, "Crustal Architecture and Evolution of the Eastern Ghats Belt and Adjacent Regions of India," Geological Society Special Publication, Vol. 206, 2003, pp. 145-168.

[12] P. Sengupta, S. Dasgupta, P. K. Bhattacharya, M. Fukuoka, S. Chakraborti and S. Bhowmmik, "Petrotectonic Imprints in the Sapphirine Granulites from Anantagiri, Eastern Ghats Mobile Belt, India," Journal of. Petrology, Vol. 31, 1990, pp. 971-996.

[13] A. Mohan, P. Tripathi and Y. Motoyoshi, "Reaction History of Sapphirine Granulites and a Decompressional P-T Path in a Granulite Complex from the Eastern Ghats," Proceedings of the Indian Academy of Sciences (Earth \& Planetary Science), Vol. 106, 1997, pp. 115-129.

[14] S. R. Bohlen, "Pressure-Temperature-Time Paths and Tectonic Model for the Evolution of Granulites," Journal of Geology, Vol. 95, No. 5, 1987, pp. 617-632. doi: $10.1086 / 629159$

[15] S. Bhattacharya, P. Das, A. K. Chaudhary and A. K. Saw, "Mafic Granulite Xenoliths in the Eastern Ghats Grannulite Belt: Implications for Lower Crustal Processes in the Southeastern Peninsular India," Journal of the Geological Society of India, Vol. 80, 2010, pp. 55-69.

[16] A. B. Thompson, "Clockwise P-T Paths for Crustal Melting and $\mathrm{H}_{2} \mathrm{O}$ Recycling in Granite Source Regions and Migmatite Terrains," Lithos, Vol. 56, No. 1, 2001, pp. 33 45. doi:10.1016/S0024-4937(00)00058-X

[17] R. Simmat and M. M. Raith "U-Th-Pb Monazite Geochronometry of the Eastern Ghats Belt, India: Timing and Spatial Disposition of Poly-Metamorphism," Precambrian Research, Vol. 162, No. 1-2, 2008, pp. 16-39. doi:10.1016/j.precamres.2007.07.016

[18] D. Mukhopadhyay and K. Basak, "The Eastern Ghats Belt-A Polycyclic Granulite Terrain," Journal of the Geological Society of India, Vol. 73, No. 4, 2009, pp. 489-518. doi:10.1007/s12594-009-0034-8

[19] P. Richard, N. Shimizu and C. J. Allegre, "143Nd/144Nd a Natural Tracer: An Application to Oceanic Basalts," Earth and Planetary Science Letters, Vol. 31, No. 2, 1976, pp. 269-278. doi:10.1016/0012-821X(76)90219-3

[20] D. J. DePaulo, "Neodynium Isotopes in the Colorado Front Range and Crust-Mantle Evolution in the Proterozoic," Nature, Vol. 291, 1981, pp. 193-196. doi: $10.1038 / 291193 \mathrm{a} 0$

[21] S. Bhattacharya, "Dehydration Melting in Mafic Rocks in 
the Eastern Ghats Belt, India: Implications for Variable Composition of Charnockitic Melt and Heterogeneity of Source Rocks," Geological Society of India Memoir, Vol. 52, 2003, pp. 131-144.

[22] S. Bhattacharya, A. K. Chaudhary, A. K. Saw and P. Das, "Mafic Granulite Xenoliths from the East Indian Shield: Evidence for Recycled Continental Crust in the Archean Mantle," Lithosphere, Vol. 3, 2011, pp. 155-169. doi:10.1130/L120.1

[23] C. Dobmeier and M. Raith, "On the Origin of "Arrested" Charnockitization in the Chilka Lake Area, Eastern Ghats Belt, India: A Reappraisal," Geological Magazine, Vol. 137, No. 1, 2000, pp. 27- 37. doi:10.1017/S0016756800003472

[24] M. V. Subba Rao and V. Divakara Rao, "Chemical Constraints on the Origin of the Charnockites in the Eastern Ghats Mobile Belt, India," Chemical Geology, Vol. 69, No. 1-2, 1988, pp. 37-48. doi:10.1016/0009-2541(88)90156-8

[25] K. Mezger and M. Cosca, "The Thermal History of the Eastern Ghats Belt (India), as Revealed by $\mathrm{U}-\mathrm{Pb}$ and 40Ar/39Ar Dating of Metamorphic and Magmatic Minerals: Implications for the SWEAT Correlation," Precambrian Research, Vol. 94, No. 3-4, 1999, pp. 251-271. doi:10.1016/S0301-9268(98)00118-1

[26] U. K. Bhui, P. Sengupta and P. Sengupta, "Phase Relations in Mafic Dykes and Their Host Rocks from Kondapalle, Andhra Pradesh, India: Implications for the TimeDepth Trajectory of the Palaeoproterozoic (Late Achaean?) Granulites from Southern Eastern Ghats Belt," Precambrian Research, Vol. 156, No. 3-4, 2007, pp. 153- 174. doi:10.1016/j.precamres.2007.03.005

[27] V. P. Kovach, R. Simmat, K. Rickers, N. G. Berezhnaya, E. B. Salnikova, C. Dobmeier, M. Raith, S. Z. Yakovleva and A. B. Kotov, "The Western Charnockite Zone of the Eastern Ghats Belt, Indian Independent Crustal Province of Late Archean (2.8 Ga) and Paleoproterozoic (1.7 - 1.6 Ga) Terrains," Gondwana Research, Vol. 4, No. 4, 2001, pp. 666-667. doi:10.1016/S1342-937X(05)70462-7

[28] D. Upadhyay, A. Gerdes and M. M. Raith, "Unraveling Sedimentary Provenance and Techtonothermal History of High-Temperature Metapelites, Using Zircon and Monazite Chemistry: A Case Study from the Eastern Ghats Belt, India," Journal of Geology, Vol. 117, 2009, pp. 665-683.

\section{doi:10.1086/606036}

[29] R. Kar and S. Bhattacharya, "New Experimental Constraints: Implications for the Petrogenesis of Charnockite of Dioritic Composition," Natural Science, Vol. 2, 2010, pp. 1085-1089. doi:10.4236/ns.2010.210135

[30] S. Bhattacharya, R. Kar, W. Teixeira and M. Basei, "High-Temperature Crustal Anatexis in a Clockwise P-T Path: Isotopic Evidence from a Granulite-Granitoid Suite in the Eastern Ghats Belt, India," Journal of Geological Society, Vol. 160, No. 1, 2003, pp. 39-46. doi:10.1144/0016-764902-063

[31] P. Sengupta, J. Sen, S. Dasgupta, M. Raith, U. K. Bhui and J. Ehl, "Ultrahigh Temperature Metamorphism of Metapelitic Granulites from Kondapalle, Eastern Ghats Belt: Implications for the Indo-Antarctic Correlation," Journal of Petrology, Vol. 40, 1999, pp. 1065-1087. doi:10.1093/petrology/40.7.1065

[32] S. Neogi, S. Dasgupta, P. Sengupta and N. Das, "Ultrahigh Temperature Decompression in a Suite of Grannulites from the Eastern Ghats Belt-Bastar Craton Contact and Its Significance," Memoir Gondwana Research Group, Vol. 5, 1999, pp. 115-138.

[33] S. Dasgupta, P. Sengupta, M. Fukuoka and S. Chakraborti, "Dehydration Melting, Fluid Buffering and Decompressional P-T Path in a Granulite Complex from the Eastern Ghats, India," Journal of Metamorphic Geology, Vol. 10, No. 6, 1992, pp. 777-788. doi:10.1111/j.1525-1314.1992.tb00122.x

[34] A. K. Saw, "Structural Setting and Petrogenesis of the Granulite-Granite-Migmatite Suite of Sunki, Koraput District, Orissa, in the Eastern Ghats Granulite Belt," Ph.D. Dissertation, Calcutta University, Kolkata , 2007

[35] S. Gupta, A. Bhattacharya, M. Raith and J. K. Nanda, "Contrasting Pressure-Temperature-Deformation History across a Vestigal Craton-Mobile Belt Boundary: The Western Margin of the Eastern Ghats Belt at Deobhog, India," Journal of Metamorphic Geology, Vol. 18, 2000, pp. 683-697. doi:10.1046/j.1525-1314.2000.00288.x

[36] M. Ramakrishnan, J. K. Nanda and P. F. Augustine, "Geological Evolution of the Proterozoic Eastern Ghats Mobile Belt," Geological Survey of India, Vol. 44, 1998, pp. 1-21. 